\title{
Efficacy of some biotic and abiotic treatments in controlling Alternariasolani the causal of tomato early blight disease in vitro and in vivo
}

\author{
Asmaa M. Ragab **; G.M. El-Habbaa*; F.G. Mohamed"; A.I.I.El-Fiki"; N.M.Abu-Zeid" \\ *Plant Pathology, Dept., Fac. Agric., Moshtohor, Benha University \\ ** Plant Pathology Research Institute, Agri. Res. Center (ARC), Giza, Egypt.
}

Corresponding Author: ghabaa@yahoo.com

\begin{abstract}
Early blight of tomato caused by Alternariasolaniis one of the most common foliar diseases of tomato. Fivetested Trichoderma isolates were most effective in reducing growth of A. solani(As-3) than the tested Bacillus isolates. The highest reduction\% was recorded with Trichodermaaureoviride- $\mathrm{I}(\mathrm{T}-1)$ followed by Trichodermaaureoviride-II (T-2), Bacillussubtilis-I (B-24) and Bacillusamyloliquefaciens-II(B-19). Spraying plants with any of the tested antagonists before inoculation with A. solani under greenhouse conditions decreased the early blight disease severity (DS) by 15.1 to $45.3 \%$ compared with the infected control treatment with the pathogen only which recorded $93.4 \%$ of DS\%. Bacillus amyloliquefaciens-II (B-19)،T. virens (T11)and T. harzianum-II (T-13) were the most effective for controlling early blight disease at 21-day post inoculation. All plant oils reduced the growth of A. solani isolate (As-3) with superiority of the high concentrations. The highest decreased $\%$ in growth of A. solani occurred with the $6.0 \%$ concentration. Among the five plant oils, cinnamon was the most effective followed by cloves then marjoram, while garlic was the least effective. Moreover, all oils at 3\% concentration were moderately effective in controlling the disease. Clove and marjoram oil were the most effective in decreasing the infection at 21-day post inoculation with the pathogen while, garlic oil was the least effective. All tested chemical inducers reduced the growth of $A$. solani(As-3) on PDA plates. The high concentration $400 \mathrm{mM}$ of sodium bicarbonate and potassium hydrogen carbonate was the most effective. Salicylic acid at 3 and $5 \mathrm{mM}$ was more effective in reducing the growth of isolate As-3 compared with the same concentrations of ascorbic acid. Spraying plants with the tested chemical inducers against early blight disease caused by $A$. solani(As-3) was moderately effective in controlling the infection. All tested chemical inducers controlled the early blight infection where the recorded DS\% was ranged between 30.1 to $45.4 \%$ at 21 day post inoculation with A. solani(As-3). Spraying tomato plants with salicylic acid was the most effective treatment in controlling $A$. solani (As-3) infection compared with the other chemical inducers.
\end{abstract}

Key words: early blight disease, Alternariasolani, mineral salts, organic acids, plant oils, Antagonists.

\section{Introduction}

Early blight is considering one of the most destructive fungal diseases affecting significantly tomato-plants (SolanumlycopersicumL.) and other plants of family Solanaceae, either in conventional or organic cultivations. Early blight of tomato, caused by the necrotrophic fungus Alternariasolani(Ellis \& Martin, 1882), is one of the most common foliar diseases of tomatoes, which damages the leaves, stalks, stems and fruits causing severe destruction of the aerial part and reduction of the size and number of fruits, resulting heavy losses in yield up to $79 \%$ (Sherf\&MacNab, 1986; Gwary\&Nahunnaro, 1998). As for biological control,Babu et al. (2000) stated that Trichodermaharzianum and $T$. viride were significantly effective in inhibiting the mycelial growth of $A$. solani although it was no significant difference between the effectiveness of Trichoderma species in pot culture studies. Also, Dar et al. (2011) revealed that the fungal antagonists may compete for an ecological niche by consuming available nutrients and by secreting a spectrum of biochemicals effective against various fungal pathogens. These biochemicals may include cell wall degrading enzymes, siderophores chelating irons, and a wide variety of volatile and non-volatile antibiotics. Moreover, Pane and Zaccardelli (2014) mentioned that four Bacillus species were capable to decrease severity of Alternaria disease on tomato. The evident inhibition zone observed in dual culture plates, suggested an antibiosis-like mechanism. Also, Zghairet al. (2014) mentioned that the bioagentsTrichodermaharzianum and Pseudomonas fluorescens (as seed treatment + two foliar sprays) were effective in reducing the tomato early blight disease intensity.Chohan et al. (2015) compared between the efficacy of three fungicides (Topsin-M, Bavistin and Ridomil Gold MZ) at $1 \mathrm{~g} / \mathrm{L}, 2 \mathrm{~g} / \mathrm{L}$ and $3 \mathrm{~g} / \mathrm{L}$ concentration and two bio-agents (Trichodermaharzianum and $T$. viride) against Alternariasolani in vitro and under tunnel cultivation. In in vitro assay, Topsin-M at $3 \mathrm{~g} / \mathrm{L}$ concentration was the most effective fungicide among the three tested and compared to control. Comparing of both bioagents, $T$. harzianum was more effective than $T$. viride in inhibiting the growth of $A$. solani. Under tunnel cultivation, early blight 
disease of tomato was significantly reduced by foliar applications of Topsin-M and T. harzianium at $3 \mathrm{~g} / \mathrm{L}$ and $10^{8}$ conidia/mL concentrations, respectively comparing with untreated plants.

Concerning the effect of plant oils, Özcan and Boyraz (2000) found that Fusariumoxysporum f. sp.phaseoli, Macrophominaphaseoli, Botrytis cinerea, Rhizoctoniasolani, Alternariasolani and Aspergillusparasiticus were completely inhibited by both of the concentrations of wild thyme and the $10 \%$ level of oregano decoctions in all the incubation periods. El-Mougy and Abdel-Kader (2007) observed the highly significant inhibitory effect on radial fungal growth at different concentrations of carnation (Dianthus caryophyllus), cinnamon (Cinnamomumburmannil), garlic (Allium sativum) and thyme (Thymus vulgaris). In the greenhouse, carnation and cinnamon spieces showed the highest protecting effect against disease incidence when applied as powder or extracts and gave a similar effect to the fungicide Rhizolex-T in reducing damping-off incidence either at pre- or postemergence stages of faba bean plants. Ajay(2009) demonstrated that Cinnamomumzeylanicum bark and leaves contain certain fungicidal constituents exhibiting potential antimicrobial activity against Alternariasolani.Lathaet al. (2009) reported that leaf extract of Zimmu (Allium cepa L. $x$ Allium sativum L.) demonstrated the highest inhibition of mycelial growth $(87 \%)$ of Alternariasolaniand caused the highest reduction of the early blight disease.Fenget al. (2011) mentioned that thyme oil possessed great fumigant and contact toxicity against Alternariaalternata at different concentrations in vitro. Thyme oil at $500 \mu \mathrm{L} / \mathrm{L}$ showed a significant contact inhibition effect on A. alternata of cherry tomatoes stored at $25^{\circ} \mathrm{C}$ for 3 days.Maya and Thippanna (2015) revealed that Rhizome extracts of Zinger officinalea recorded maximum mycelial inhibition followed by $M$. azardichita,P. guajava,P. pinnata,E. Odoratum, and Cassia torawithwhich was the least inhibitor of mycelia when evaluated ten locally available aqueous botanical extracts against Alternariasolani.

Regarding the effect of chemical inducers, Janisiewicz and Peterson, (2005) revealed that spraying of plants with $\mathrm{NaHCO}_{3}$ solution was provided good control of several plant diseases. EIGamal et al. (2007) evaluated the ascorbic acid (AA), dichloro-isonicotinic acid (INA), ethylene diamine tetra acetic acid (EDTA) and calcium chloride against late and early blight diseases under greenhouse and field conditions. Under greenhouse conditions, the highest reduction in disease severity was obtained by AA at $2 \& 3 \mathrm{~g} / 1$, and INA at 50.0 and $100 \mathrm{mM}$, which reduced late and early blight severity more than 75.0 and $82.1 \%$, followed by EDTA and calcium chloride, respectively. On the other hand, the combined treatments between AA at $2 \mathrm{~g} / \mathrm{L}$ and INA at 50 or $100 \mathrm{mM}$ reduced the late and early diseases severity between (86.6-90.0\%) and (90.0-93.3\%), respectively. El-Mougy and AbdelKader (2009) recorded the suppressive effect of sodium bicarbonate and calcium chloride applied individually or combined with the yeast Saccharomyces cerevisiae against Alternariasolani of potato in vitro and in vivo.

This work aimed to evaluate the efficacy of some biotic and abiotic treatments in controlling Alternariasolani the causal of tomato early blight disease in vitro and in vivo.

\section{Materials and Methods}

\section{Source of early blight pathogen:}

Out of 14 Alternariasolani isolates which isolated from different localities of seven governorates, $A$. solani isolate(As-3) which isolated from leaves of cultivated tomato plants in Kaha locality (Qalubia governorate) during spring of season 2012 was chosen for the further studies based on its highly pathogenic potentialities in inducing the early blight disease comparing with the others tested isolates of A. solani.

\section{Source of tested antagonists:}

Out of sixteen bacterial and thirteen fungal isolates isolated from tomato phylloplane and tested in vitro for their antagonistic activities, five antagonistic isolates ofTrichodermai.e., T-1, T-2, T-3, T-11 and $\mathrm{T}-13$ were identified as Trichodermaaureoviride-I(T1)and Trichodermaaureoviride-II (T-2), $T$. harzianum-I (T-3), T. harzianum-II (T-13) and one isolate $T$. virens (T-11)according to Samuels et al., (2009). Whereas, five bacterial isolates among the sixteen tested were found to be the highly antagonistic ones. These isolates were identified as Bacillusamyloliquefaciens-I(B-

2),Bacillusamyloliquefaciens-II(B-19), B. subtilis-I (B-24), B. subtilis-II (B-15) andone isolate of Bacillus leavolactius(B-17)according to Bergey's manual(Claus and Berkeley, 1986). These identified fungal and bacterial isolates which having the highly antagonistic potentialities were used in the further studies of biological control in vitro and under greenhouse conditions in addition to two bioformulations i.e., Bio-Arc and Bio-Zeid as well as one fungicide (Bellis) as control. These antagonists were tested for their antagonistic effects against early blight disease by spraying tomato plants with two sprays at 2 and 16 days before inoculation with the causal pathogen $A$. solani (As-3) two days post the last spray.

\section{In vitro tests:}

3.1. Effect of some bioagentson growth of $A$. solani (As-3) isolate:

In this trail, five antagonistic isolates of Trichodermai.e.,Trichodermaaureoviride-I(T-1)and Trichodermaaureoviride-II (T-2), T. harzianum-I (T- 
3), T. harzianum-II (T-13) and one isolate T. virens $(\mathrm{T}-11)$ in addition to five bacterial isolates i.e., Bacillusamyloliquefaciens-I(B-

2),Bacillusamyloliquefaciens-II(B-19), B. subtilis-I (B-24), B. subtilis-II (B-15) andone isolate of Bacillus leavolactius(B-17) were tested in vitro for their antagonistic abilities against A. solani (As-3) isolate the causal pathogen of tomato early blight. In this respect, Petri plates $(9 \mathrm{~cm} \varnothing)$ containing $20 \mathrm{~mL}$ PDA were inoculated with an equal disc $(5 \mathrm{~mm})$ of the bio-agents i.e., Trichodermaisolates and Bacillus subtilis (by streaking) onto one side of the prepared Petri plates. At the same time, equal discs $(5 \mathrm{~mm} \varnothing)$ of A. solani were added separately in the opposite side of the inoculated Petri plates. Three replicates were used for each particular treatment. Petri plates containing the PDA medium and inoculated with the pathogenic fungus only was used as control. All the previous treatments were incubated at $25^{\circ} \mathrm{C}$ for seven to ten days. The growth of each treatment was measured when the mycelial growth of the pathogenic fungus in the control completely covered the medium surface, then the reduction percentage was calculated using the following formula according to Fokemma (1973).

$\begin{aligned} & \text { Reduction } \\ & \text { percentage }=\end{aligned}$
Where:
de $=$ Mean diameter of growth in control.
di $=$ Mean diameter of growth in treatment

\subsection{Effect of some plant oils on growth of $A$. solani (As-3) isolate:}

In this experiment, oils extracted from several plants i.e., thymol (Thymus vulgaris); marjoram (Origanummajorana); clove (Dianthus curyaphulus); garlic (Alliumsativum) and cinnamon (Cinnamomumverum) were used to study their effects on the growth of A. solani. Benzene was added to each one of the concentrated plant oils to increase their solubility Fahiem, (2010). Different concentrations i.e., 2, 3, 4, 5 and $6 \%$ were made and each one of the prepared concentrations was added to the melted PDA medium before pouring into Petri plates. Oils were dissolved in $2 \%$ benzene. Then the poured media were left to solidify. An equal disc (5 $\mathrm{mm} \varnothing$ ) of $A$. solani was added separately to the center of the Petri plates. Three plates were used for each treatment. Control treatment was in form of inoculated plates without adding any of the tested plant oils, while benzenewas added with $2 \%$ to medium. All inoculated plates were incubated at $25^{\circ} \mathrm{C}$ for $7-10$ days then the plates were examined. The percentage of growth reduction of $A$. solani were calculated as mentioned above.

\subsection{Effect of some mineral salts on growth of $A$.} solani (As-3) isolate:
This experiment was carried out to evaluate some mineral salts on the growth of the pathogenic fungus under in vitro conditions. In this respect, sodium bicabonateat concentration of 100, 200 and $400 \mathrm{mM}$, potassium hydrogen carbonate at concentration of 100,200 and $400 \mathrm{mM}$, ascorbic acid at concentration of $1,2,3$ and $5 \mathrm{~m} . \mathrm{Mol}$, and salicylic acid at concentration of $1,2,3$ and $5 \mathrm{~m} . \mathrm{Mol}$, were tested to study their effects on growth of A. solani (As-3) isolate. Each one of the tested concentrations of each salt was mixed separately with the melted PDA medium before pouring into Petri plates, and then they were left to solidify. The discs $(5 \mathrm{~mm} \varnothing)$ of $A$. solani were added individually in the center of the poured PDA plates. Each treatment was replicated 3 times. Control treatment was made by inoculating a disc of A. solani onto PDA plate without any salt. All treatments were incubated at $20-22^{\circ} \mathrm{C}$ for $7-10$ days. The diameters of developed colonies were measured using the formula suggested by Fokemma (1973) that mentioned above.

\section{Greenhouse tests (In vivo):}

Tomato transplants (hybrid Hypeel 303) obtained from the commercial greenhouses in Tersavillage were used in greenhouse studies.

\subsection{Effect of some bioagents in controlling tomato early blight under greenhouse conditions:}

In this trail, the previously tested antagonistic fungal and bacterial isolates (Trichodermaspp and Bacillus spp.) in vitro trail were tested for their antagonistic potentialities in controlling early blight disease under greenhouse conditions. Additionally, two commercial formula of antagonists i.e., Bio-Zeid and Bio-Arc as well as Bellis fungicide were tested also for this purpose.

\section{-Preparation of bioagentinocula:}

The antagonistic bacteria were grown on nutrient broth medium (Abd-Allaet al., 2007). The bacterial isolates were incubated in a rotary shaker at $200 \mathrm{rpm}$ for $24 \mathrm{~h}$ at $28 \pm 2^{\circ} \mathrm{C}$. The bacterial cells were harvested by centrifugation at $6,000 \mathrm{rpm}$ for $10 \mathrm{~min}$, washed twice with $0.05 \mathrm{M}$ phosphate buffer at $\mathrm{pH} 7.0$ and resuspended in sterilized distilled water. The concentrations of bacteria were adjusted to $1 \times 10^{5}-10^{6}$ cells per milliliter(cfu/mL) using dilution plate assayAbdel-Kaderet al., (2012). Meanwhile, the tested antagonistic fungi were grown on PDA mediumandincubated for one week at $25 \pm 2^{\circ} \mathrm{C}$. Ten $\mathrm{mL}$ of sterilized distilled water were added to each plate then, the fungal conidia were harvested by scraping the surface of the colonies with a fine brush and then, filtered through nylon mesh. The collected spore suspension was adjusted to $1 \times 10^{4}-10^{5}$ spore per milliliter with the aid of a haemocytometer slide as described by Abd-Allaet al. (2007).

- Preparation of A. solani (As-3) inoculum:

The pathogen inoculum was prepared by culturing $A$. solani (As-3) isolate onto PDA medium at $25^{\circ} \mathrm{C}$ 
for 15 days, then $10 \mathrm{ml}$ of sterile distilled water was added to each plate and colonies were carefully scrapped with a sterile fine brush. The resulting spore suspension of As-3 isolate was adjusted to $5 \times 10^{5} \mathrm{cfu}$ $/ \mathrm{mL})$.

\section{- Application of antagonists and early blight pathogen:}

Pottery pots $(30 \mathrm{~cm}$. in diameter) were filled with sterilized sandy- clay soil $(1: 1 \mathrm{v} / \mathrm{v}, 5 \mathrm{Kg} / \mathrm{pot})$, Three seedlings of hybrid Hypeel 303 per pot were transplanted. Pots were kept under greenhouse at temperature at $22-25^{\circ} \mathrm{C}$, relative humidity about 85 $90 \%$ and irrigated periodically (10 days interval). Each treatment was replicated as 8 pots. Each replicate of transplanted tomato plants one-week old post transplanting was sprayed with $30 \mathrm{ml}$ of the tested antagonist treatments for the first time, then two weeks later, the second spray was applied. Two days post the second foliar spray with the tested antagonists; artificial infection with $A$. solaniisolate(As-3) was carried out as foliar spraying of pathogen suspensionAbdel-Kaderet al., (2013). Control treatments were in form of treated plants with Bellis fungicide pre inoculation with the tested early blight pathogen, Infected plants only with the tested early blight pathogen without spraying of any treatment pre inoculation and un-sprayed plants with any one of the tested treatments and without inoculation of the tested pathogen. Disease severity $\%(\mathrm{DS} \%)$ was calculated based on the percentage of leaf area covered with lesions where the infected plants were rated using the modified scale $(0-10)$ by James (1971) as follows: 0: No symptoms, 1:1-5\% of leaf area covered with lesions, $2: 6-15 \%$ of leaf area covered with lesions, $3: 16-30 \%$ of leaf area covered with lesions, $4: 31-45 \%$ of leaf area covered with lesions, 5:46-59\% of leaf area covered with lesions, $6: 60-69 \%$ of leaf area covered with lesions, $7: 70-79 \%$ of leaf area covered with lesions, $8: 80-89 \%$ of leaf area covered with lesions,9:90-99\% of leaf area covered with lesions and 10: Plants totally died.

Disease severity (\%) was calculated at 7,14 and 21 days post inoculation with the tested early blight pathogen(As-3 isolate) using the equation suggested by Townsend and Heuberger (1943) as follows:

Disease severity $(\%)=\frac{\sum(\mathrm{n} \times \mathrm{r})}{\mathrm{NR}}$

Where:

$\mathrm{n}=$ Number of infected leaves on the plant.

$\mathrm{N}=$ Total number of leaves examined.

$r=$ Numerical rate of infected leaves.

$\mathrm{R}=$ Highest numeric rate.

4.2 Effect of some plant oils in controlling tomato early blight under greenhouse conditions:
In this trail, the five tested plant oilsi.e.,thymol, marjoram, clove, garlic and cinnamon which previously tested in vitro were tested again in vivo under greenhouse conditions to evaluate their effects in controlling early blight infection by applying them twic eat $3 \%$ concentration on tomato plants pre inoculation with the pathogen as mentioned above. Control treatment was un-sprayed plants with any one of the tested plant oils and without inoculation of the tested pathogen. DS\% were determined at 7, 14 and 21 days post inoculation with the tested pathogen as mentioned above.

\subsection{Effect of some mineral salts in controlling tomato early blight under greenhouse conditions:}

In this trail also, the previously four tested chemical inducersin vitro in form of two mineral salts i.e., sodium bicarbonate and potassium hydrogen carbonate at three concentrations in addition to, two organic acids i.e., ascorbic acid and salicylic acid were tested again in vivo under greenhouse conditions at $100 \mathrm{mM}$ of the two tested mineral salts and at $5 \mathrm{mM}$ of the two tested organic acids to evaluate their effects in controlling early blight infection by applying them twice on tomato plants pre inoculation with the pathogen as mentioned above. Control treatment was in form of treated plants with Bellis fungicide pre inoculation with the tested early blight pathogen.DS\% were determined at 7, 14 and 21 days post inoculation with the tested pathogen as mentioned above.

\section{Results and Discussion}

1. Effect of some fungal and bacterial antagonists on tomato early blight disease and its pathogen under in vitro and in vivo conditions:

\subsection{On growth of $A$. solani(As-3) in vitro:}

Data in Table 1 indicate that all five tested fungal and bacterial isolates as antagonists to A. solani (As3 ), the causal pathogen of tomato early blight disease reduced the growth of the pathogen to high extent in vitro. In this respect, all five tested Trichoderma isolates were more effective in reducing the growth of As-3 isolate than the tested Bacillus isolates as antagonists. The highest reduction $\%$ was recorded with Trichodermaaureoviride-I(T-1) followed by Trichodermaaureoviride-II (T-2) and Trichodermavirens (T-11) while the least effective Trichoderma isolate among the five tested was Trichodermaharzianum-I (T-3). On the other hand, the most effective Bacillus isolate among the five tested was Bacillussubtilis-I (B-24) followed by Bacillusamyloliquefaciens-II(B-19) while, the least effective one in reducing the growth of As-3 isolate was Bacillus subtilis-II (B-15) followed by Bacillusamyloliquefaciens-I(B-2). 
Table 1. Antagonistic potentialities of tested antagonists against A. solani(As-3) isolate in vitro.

\begin{tabular}{lcc}
\hline Antagonist & $\begin{array}{c}\text { Linear growth } \\
\text { (mm) }\end{array}$ & Reduction\% \\
\hline Trichodermaaureoviride-I(T-1) & 24.1 & 73.22 \\
Trichodermaaureoviride-II (T-2) & 24.8 & 72.44 \\
Trichodermaharzianum-I (T-3) & 29.5 & 67.22 \\
Trichodermavirens (T-11) & 25.0 & 72.22 \\
Trichodermaharzianum-II (T-13) & 28.0 & 68.88 \\
Bacillusamyloliquefaciens-I(B-2) & 61.0 & 32.2 \\
Bacillussubtilis-II (B-15) & 61.7 & 31.4 \\
Bacillus leavolactius(B-17) & 60.1 & 33.2 \\
Bacillusamyloliquefaciens-II(B-19) & 59.1 & 34.3 \\
Bacillussubtilis-I (B-24) & 57.5 & 36.1 \\
\hline Control & 90.0 & 0.0 \\
\hline
\end{tabular}

1.2. On early blight infection under greenhouse conditions (in vivo).

In this trail, five antagonistic isolates of Trichoderma and five isolates of Bacillus in addition to two bioformulations (Bio-Arc and Bio-Zeid) and one fungicide (Bellis) as control were tested for their antagonistic effects against early blight disease by spraying tomato plants with two sprays at 2 and 16 days before inoculation with the causal pathogen $A$. solani (As-3) two days post the last spray.

Data in Table 2 indicate that spraying tomato plants with any one of the tested antagonists before inoculation with $A$. solani under greenhouse conditions decreased the early blight disease severity to values ranged between $15.1-45.3 \%$ compared with the infected control treatment with the pathogen only which recorded $93.4 \%$ of DS\% at 21-day post inoculation with the pathogen. In this respect, Bacillus amyloliquefaciens-II (B-19)‘T. virens (T11)and $T$. harzianum-II (T-13) were the most effective treatments for controlling the early blight disease at 21-day post inoculation where they recorded 15.1, 21.1 and $25.4 \%$ of DS\% respectively. T. harzianum-I (T-3), T. aureoviride-I (T-1) and T. aureoviride-I (T-2) came in the second rank where they recorded $30.1,30.2$ and $31.1 \%$ of disease severity respectively. Meanwhile, B. leavolactius(B17), B. subtilis-II (B-15) and B. amyloliquefaciensI(B-2) were the least effective ones in decreasing the early blight disease severity caused by $A$. solani compared with the other tested antagonists under greenhouse conditions which recorded 45.3, 42.2 and $40.8 \%$ of disease severity respectively. On the other hand, Bellis fungicide and Bio-Arc formulation treatments reduced the early blight DS\% to values similar to those recorded with the first group of antagonists were they recorded 15.3 and $25.1 \%$ of disease severity at 21-day post inoculation. Whereas, the recorded DS\% with Bio-Zeid treatment was $35.3 \%$ which almost similar with the results of the second group of tested antagonists at 21-day post inoculation with the early blight pathogen (As-3). Moreover, the recorded DS\% at 21-day with all tested antagonists were higher than those recorded at
14 and 7 days post inoculation with the pathogen. The in vitro and in vivo results are in agreement with those obtained by Tran (2010) who reported that Trichoderma species have become popular biological agents to protect crops against plant pathogens all over the world. Researchers have indicated that they can parasitize fungal pathogens and produce antibiotics.Also,Fontenelle $\boldsymbol{e t}$ al. (2011) revealed that treating the soil with 28 Trichoderma isolates provided protection in tomato plants from 30.69 to $95.23 \%$ against $A$. solani the causal agent of early blight disease at all-time intervals, confirming the ability of the isolates to reduce the severity of these diseases up to 21 days after treatment of tomato plants. Yaziciet al. (2011) confirmed that 23 bacterial isolates were able to inhibit the mycelial growth of Alternariasolani by forming inhibition zone ranging from 9.35 to $31.3 \mathrm{~mm}$. The most effective isolate was Serratiaplymuthica (IK- 139). In whole plant tests, bacterial isolates of Paenibacillusmacerans-GC subgroup A, Serratiaplymuthica, Bacillus coagulans, Serratiamarcescens-GC subgroup A, Bacillus pumilis-GC subgroup B and Pantoeaagglomerans (1.32) reduced significantly disease severity of early blight when compared with control in tomato. In addition, Prajapati et al. (2014) found thatTrichodermaviride, T. harzianum and $T$. virens are promising antagonists against Alternariasolani under in vitro evaluation carried out by dual culture technique for growth inhibition. Trichoderma not only overgrew the host fungus $A$. solani, but also it caused mycelialcoiling. Also, Ramanujam et al. (2015) evaluated the fungal and bacterial antagonists against early blight pathogen of tomato, Alternariasolani under in vitro, glasshouse and field conditions. Among the isolates tested, Trichodermaharzianum (Th-7) showed significant inhibition of $A$. solani under in vitro and glasshouse conditions. Seedling dip and foliar applications of $T$. harzianum (Th-7), T. viride (Tv-14) and $P$. fluorescens (Pf-1) decreased the early blight disease incidence up to $62 \%$ and increased the tomato yield up to $37 \%$ over control in field trials. 
Table 2. Effect of some tested antagonists on tomato early blight disease severity caused by A. solani (As-3) at different incubation periods under greenhouse conditions.

\begin{tabular}{lcccc}
\hline Antagonist & \multicolumn{3}{c}{ Disease severity \% at days } & Mean \\
\cline { 2 - 4 } & $\mathbf{7}$ & $\mathbf{1 4}$ & $\mathbf{2 1}$ & 23.2 \\
\hline T. aureoviride-I (T-1) & 16.0 & 23.5 & 30.2 & 20.7 \\
T. aureoviride-II (T-2) & 10.5 & 20.3 & 31.1 & 24.8 \\
T. harzianum-I (T-3) & 17.0 & 27.4 & 30.1 & 16.5 \\
T. harzianum-II (T-13) & 8.3 & 15.8 & 25.4 & 15.5 \\
T. virens (T-11) & 9.9 & 15.5 & 21.1 & 27.0 \\
B. subtilis-I (B-24) & 13.5 & 30.2 & 37.3 & 31.2 \\
B. subtilis-II (B-15) & 21.1 & 30.3 & 42.2 & 29.5 \\
B. amyloliquefaciens-I (B-2) & 17.5 & 30.7 & 40.4 & 13.4 \\
B. amyloliquefaciens-II (B-19) & 10.2 & 15.0 & 15.1 & 35.4 \\
B. leavolactius(B-17) & 25.5 & 35.4 & 45.3 & 24.0 \\
Bio-Zeid & 16.5 & 20.3 & 35.3 & 16.0 \\
Bio-Arc & 7.5 & 15.3 & 25.1 & 13.7 \\
Bellis fungicide & 10.7 & 15.1 & 15.3 & 81.4 \\
Infected control & 68.7 & 81.8 & 93.4 & 1.8 \\
Control & 00.0 & 00.0 & 5.3 & \\
\hline L.S.D at 5\% & \multicolumn{3}{c}{} \\
\hline
\end{tabular}

2. Effect of some plant oils on tomato early blight disease and its pathogen under in vitro and in vivo conditions:

In this trail, five plant oils i.e.,Garlic,Cinnamon, Cloves, Marjoram, and Thyme were tested to show their effects on the mycelial growth of $A$. solani isolate (As-3) in vitro and early blight infection under greenhouse conditions (in vivo).

\subsection{On growth of $A$. solani(As-3) in vitro:}

Different concentrations of the five tested plant oils i.e., 2, 3, 4, 5 and $6 \%$ were tested to show their effects on growth of $A$. solani(As-3) isolate. Data in Table 3 indicate that all tested plant oils reduced the growth of $A$. solani(As-3) isolate with superiority of the high concentrations than the low ones in their effects.

Table 3. Effect of plant oils on the growth of A. solani (As-3) in vitro.

\begin{tabular}{|c|c|c|c|}
\hline Plant Oil & Conc. (\%) & Linear growth & Reduction \% \\
\hline \multirow{5}{*}{ Cinnamon } & 2 & 90.0 & 0.0 \\
\hline & 3 & 83.6 & 7.1 \\
\hline & 4 & 77.2 & 14.3 \\
\hline & 5 & 55.2 & 38.7 \\
\hline & 6 & 00.0 & 100.0 \\
\hline \multirow{5}{*}{ Marjoram } & 2 & 90.0 & 0.0 \\
\hline & 3 & 74.0 & 17.8 \\
\hline & 4 & 67.0 & 25.5 \\
\hline & 5 & 50.5 & 43.9 \\
\hline & 6 & 40.0 & 55.5 \\
\hline \multirow{5}{*}{ Thyme } & 2 & 90.0 & 0.0 \\
\hline & 3 & 86.6 & 3.8 \\
\hline & 4 & 80.3 & 10.8 \\
\hline & 5 & 76.0 & 15.6 \\
\hline & 6 & 62.0 & 31.1 \\
\hline \multirow{5}{*}{ Garlic } & 2 & 90.0 & 0.0 \\
\hline & 3 & 85.5 & 5.0 \\
\hline & 4 & 84.7 & 5.8 \\
\hline & 5 & 81.0 & 10.0 \\
\hline & 6 & 75.5 & 16.1 \\
\hline \multirow{5}{*}{ Clove } & 2 & 69.0 & 23.3 \\
\hline & 3 & 56.0 & 37.78 \\
\hline & 4 & 35.3 & 60.8 \\
\hline & 5 & 30.2 & 66.39 \\
\hline & 6 & 22.0 & 75.55 \\
\hline ntrol (benzene) & & 90.0 & 0.0 \\
\hline
\end{tabular}


In this respect, it was pronounced from results that the most reduction\% in growth of $A$. solani was obtained with the concentration $6.0 \%$ of all tested plant oils. Among the five tested plant oils, cinnamon was the most effective oil where it reduced the growth of $A$. solani to $100 \%$ followed by cloves $(75.6 \%)$ then marjoram $(55.6 \%)$, while garlic was the least effective oil $(16.1 \%)$. The control treatment with benzene had no effect on the mycelial growth reduction of the pathogen.

\subsection{On early blight infection under greenhouse conditions (in vivo).}

Results in Table 4 illustrated that all tested plant oils at $3 \%$ concentration were moderately effective in controlling the early blight infection under greenhouse conditions. On the other hand, clove and marjoram oil were the most effective plant oils in decreasing early blight infection where they recorded 46.2 and $48.6 \%$ respectively of DS\% at 21-day post inoculation with the pathogen comparing with the others tested. Meanwhile, garlic oil was the least effective one where it recorded $66.2 \%$ of DS. It is clear from the obtained results that in spite of spraying tomato plants with the tested oils before inoculation with early blight pathogen (As-3), the recorded DS\% were increased with increasing the incubation periods to be the higher at 21-day than at 14 and 7 days.

Table 4. Effect of some plant oils on tomato early blight disease infection caused by A. solani (As-3) at different incubation periods under greenhouse conditions.

\begin{tabular}{lccccc}
\hline \multirow{2}{*}{ Plant oil } & & \multicolumn{3}{c}{ Disease severity \% at days } & \multirow{2}{*}{ Mean } \\
\cline { 3 - 5 } & Conc. $(\boldsymbol{\%})$ & $\mathbf{7}$ & $\mathbf{1 4}$ & $\mathbf{2 1}$ & 45.29 \\
Cinnamon & 3 & 35.34 & 44.40 & 56.12 & 38.32 \\
Marjoram & 3 & 30.29 & 36.11 & 48.57 & 43.10 \\
Thyme & 3 & 32.91 & 40.52 & 55.87 & 52.50 \\
Garlic & 3 & 41.54 & 49.73 & 66.23 & 37.16 \\
Clove & 3 & 29.51 & 35.74 & 46.22 & 1.8 \\
Control & & 00.0 & 00.0 & 5.3 & \\
\hline
\end{tabular}

The obtained results of the effect of plant oils onto early blight disease in vitro and in vivo could be interpreting in light the findings of Amadioha (2000) who suggested that the mechanisms of disease suppression by plant products have the active principles present in plant extracts may act on the pathogen directly. Also, Abou-Jawdah et al. (2002) reported that wild marjoram (Origanumsyriacum) extract showed the highest and widest range of antimycotic activity against eight phytopathogenic fungi among them Alternariasolani where it resulted complete inhibition of mycelial growth. Also, Wszelaki and Miller (2005) reported that garlic extracts reduced significantly the early blight disease on tomato. El-Mougy (2009) studied the effect of carnation, caraway, thyme oils and Ridomil-MZ fungicide at various concentrations on mycelial growth of Alternariasolani. Carnation oil had the strongest inhibitory effect on fungal growth. Slightly less effective were caraway and thyme oils followed by the chemical fungicide. Extended field trials for two cultivation seasons proved that the application of essential oils twice as foliar spray had a superior effect to the fungicide treatment for reducing the early blight incidence comparing with untreated control. In addition, these results are in harmony with those recorded by Maya and Thippanna (2015).

3. Effect of some chemical inducers on tomato early blight disease and its pathogen under in vitro and in vivo conditions:

In this trail, four chemical inducers in form of two mineral salts i.e., sodium bicarbonate and potassium hydrogen carbonate at three concentrations (100, 200 and $400 \mathrm{mM}$ ) in addition to, two organic acids i.e., ascorbic acid and salicylic acid at 4 concentrations $(1,2,3$ and $5 \mathrm{mM})$ were tested in vitro to show their effects on growth of $A$. solani(As-3) isolate as well as, their effects on early blight disease severity under greenhouse conditions.

\subsection{On growth of $A$. solani(As-3) in vitro:}

Data in Table 5 indicate that all tested chemical inducers reduced the growth of $A$. solani(As-3) on PDA plates compared with growth on water-treated cultures (control). Also, it was found a positive relation between the high concentration of the tested mineral salts and the recorded reduction $\%$ of $A$. solani growth where the high concentration $400 \mathrm{mM}$ of both tested salts was the most effective one than others tested. As for tested organic acids, data indicate that salicylic acid at 5 and $3 \mathrm{mM}$ was more effective in reducing the growth of As-3 isolate comparing with the same concentrations of ascorbic acid.

\subsection{On tomato early blight infection under greenhouse conditions.}

Results in Table 6 reveal that spraying tomato plants with the tested chemical inducers (mineral salts or organic acids) against early blight disease caused by A. solani(As-3) was moderately effective in controlling the infection. Also, it is clear from the obtained results that all tested chemical inducers controlled the early blight infection where the 
recorded DS\% were ranged between $30.1-45.4 \%$ at 21-day post inoculation with A. solani (As-3). Spraying tomato plants with salicylic acid was the most effective treatment in controlling A. solani (As3 ) infection under greenhouse conditions comparing with the other tested chemical inducers. In general, the tested organic acids were more effective than the tested mineral salts however, all tested chemical inducers were less effective than Bellis fungicide in controlling early blight infection. The recorded DS\% post inoculation with the pathogen post spraying with each one of the tested chemical inducers was gradually increased with increasing days post inoculation from 7-21-day. The obtained results on the effect of some chemical inducers on early blight pathogen in vitro and in vivo are in harmony with those obtained by Fallik et al. (1997) who reported that the inhibitory effect of sodium bicarbonate on microorganisms may be due to reduction of cell turgor that causes a collapse and shrinkage of hyphal and spores. Also, Spletzer and Enyedi (1999) mentioned that salicylic acid (SA) is an important signal molecule that plays a critical role in plant defense against pathogen invasion. Data indicate that root feeding $200 \mu \mathrm{M} \mathrm{SA}$ to tomato plants can (i) significantly elevate foliar SA levels, (ii) induce PR$1 \mathrm{~B}$ gene expression, and (iii) activate SAR that is effective against Alternariasolani. Moreover, the recorded results of El-Gamalet al. (2007) and ElMougy and Abdel-Kader (2009) supported the obtained results in this work.

Table 5. Effect of some chemical inducers on growth of A. solani (As-3) under laboratory conditions.

\begin{tabular}{|c|c|c|c|}
\hline Chemical inducer & $\begin{array}{l}\text { Conc. } \\
(\mathbf{m M})\end{array}$ & Linear growth & Reduction \% \\
\hline & \multicolumn{3}{|c|}{ Mineral salts } \\
\hline \multirow{3}{*}{ Sodium bicabonate } & 100 & 23.3 & 74.1 \\
\hline & 200 & 12.5 & 86.1 \\
\hline & 400 & 10.0 & 88.9 \\
\hline \multirow{3}{*}{ Potassium hydrogen carbonate } & 100 & 37.0 & 58.9 \\
\hline & 200 & 23.7 & 73.7 \\
\hline & 400 & 12.3 & 86.3 \\
\hline \multirow{5}{*}{ Ascorbic acid } & \multicolumn{3}{|c|}{ Organic acids } \\
\hline & 1 & 87.5 & 2.8 \\
\hline & 2 & 73.5 & 18.3 \\
\hline & 3 & 49.5 & 45.0 \\
\hline & 5 & 32.5 & 63.9 \\
\hline \multirow{4}{*}{ Salicylic acid } & 1 & 90.0 & 0.0 \\
\hline & 2 & 56.6 & 37.1 \\
\hline & 3 & 28.1 & 68.8 \\
\hline & 5 & 13.3 & 85.2 \\
\hline Control & & 90 & 0.00 \\
\hline
\end{tabular}

Table 6. Effect of some chemical inducers on the disease severity on tomato plants caused by A. solani under greenhouse conditions.

\begin{tabular}{cccccc}
\hline Chemical inducer & Conc. & \multicolumn{2}{c}{ Disease severity \% at days } & \multirow{2}{*}{ Mean } \\
\cline { 5 - 6 } & $(\mathbf{m M})$ & $\mathbf{7}$ & $\mathbf{1 4}$ & $\mathbf{2 1}$ & \\
\hline Sodium bicabonate & 100 & 16.6 & 35.3 & 40.1 & 30.7 \\
\hline Potassium hydrogen carbonate & 100 & 27.5 & 40.4 & 45.4 & 37.8 \\
\hline Ascorbic acid & 5 & 15.5 & 27.6 & 35.8 & 26.3 \\
\hline Salicylic acid & 5 & 12.8 & 20.4 & 30.1 & 21.1 \\
\hline Bellis fungicide & $0.5 \mathrm{~g} / \mathrm{L}$ & 10.7 & 15.1 & 15.3 & 13.7 \\
\hline
\end{tabular}

\section{References}

Abd-Alla, M. A., El-Mohamedy, R. S. and ElMougy, N. S. (2007). Control of sour rot disease of lime fruits using saprophetic isolates of yeast. Egypt J. Phytopathol., 35 (2):39-51.

Abdel-Kader, M.M., El-Mougy, N.S., Aly, M.D.E. and Lashin S. M. (2012).Integration of Biological and Fungicidal Alternatives for
Controlling Foliar Diseases of Vegetables under Greenhouse .Conditions International Journal of Agriculture and Forestry, 2(2): 38-48 .

Abdel-Kader, M.M., El-Mougy N.S. and Lashin S.M. (2013). Biological and Chemical Resistance Inducers Approaches for Controlling Foliar Diseases of Some Vegetables under Protected Cultivation System. J Plant Pathol Microb 4:200 
Abou-Jawdah, Y.,Sobh, Y., and Salameh, A. (2002). Antimycotic activities of selected plant flora, growing wild in lebanon, against phytopathogenic fungi. J. Agric. Food Chem., 50 (11):3208-3213.

Ajay, K.M., Mishra, A., Kehri, H.K., Sharma, B. and Pandey, A.K. (2009). Inhibitory activity of Indian spice plant Cinnamomumzeylanicum extracts against Alternariasolani and Curvularialunata, the pathogenic dematiaceousmoulds. Annals of Clinical Microbiology and Antimicrobials, 8(9): 1-7

Amadioha A.C. (2000). Controlling rice blast in vitro and in vivo with extracts of Azadirachtaindica. Crop Protection, 19: 287-290.

Babu, S., Seetharaman, K., Nanda, Kumar, R. and Johnson, I. (2000). Variations in conidial morphology of Alternariasolani causing tomato leaf blight disease. Annals of Plant protectionSci., 8 (1) : $100-102$.

Chohan, S.,Perveen, R., Mehmood, M.A., Safina N.andAkram,N.(2015).Morpho-physiological studies, management and screening of tomato germplasm against Alternariasolani, the causal agent of tomato early blight. International Journal of Agriculture and Biology17:111-118.

Claus. D. and Berkeley, R.C.W. (1986).Genus Bacillus Cohn 1872, 174AL. In: Sneath, P.H.A., Mair, N.S., Sharpe, M.E. and Holt, J.G., editor(s). Bergey's manual of systematic bacteriology. Baltimore, USA: Williams and Wilkins; 1986. p. 1105-38.

Dar, G.H., Beig, M.A., Ahanger, F.A., Ganai, N. A. and Ahangar, M.A. (2011).Management of root rot caused by Rhizoctoniasolaniand Fusariumoxysporumin Blue Pine (Pinuswallichiana) through use of fungal antagonists. Asian Journal of Plant Pathology, 10:1819-1541.

El-Gamal, N.G., Abd-El-Kareem, F., Fotouh, Y.O. and El-Mougy, Nehal, S. (2007). Induction of systemic resistance in potato plants against late and early blight diseases using chemical inducers under greenhouse and field conditions. Research Journal of Agriculture and Biological Sciences, 3(2):73-81.

Ellis, J.B. and Martin, G.B. (1882).Macrosporiumsolani E\&M. American Naturalist, 16: 1003.

El-Mougy, N.S. (2009).Effect of some essential oils for limiting early blight (AlternariaSolani) development in potato field. Journal of Plant Protection Research, 49: 57-62.

El-Mougy, N.S. and Abdel-Kader, M. (2007). Antifungal effect of powdered spices and their extracts on growth and activity of some fungi in relation to damping-off disease control. Journal of plant protection research, 47: 3 .

El-Mougy, N.S. and Abdel-Kader, M. (2009).Salts application for suppressingpotato early blight disease. Journal of plant protection research, 49(4):353-361

Fahiem, M.A. (2010). Studies on bean fruit in Egypt. M. Sc. Thesis, Fac. Agric., Benha Univ. Pp.

Fallik, E., Grinberg, S. and Ziv, O. (1997). Potassium bicarbonate reduces postharvest decay development on bell pepper fruits. J. Hortic. Sci. 72:35-41.

Feng, W., Chen, J., Zheng, X. and Liu, Q. (2011). Thyme oil to control Alternariaalternatain vitro and in vivo as fumigant and contact treatments. Food Control.22: 78-81.

Fokemma, N.J. (1973). The role of saprophytic fungi in antagonism against Drechslerasarokiniana

(Helminthosporiumsativum) on agar plates and on rye leaves with pollen. Physical Plant Pathol., (3) :195-205.

Fontenelle, A.D.B., Guzzo, S. D., Lucon, C.M.M. and Harakava, R. (2011). Growth promotion and induction of resistance in tomato plant against Xanthomonaseuvesicatoria and Alternari asolani byTrichoderma spp. Crop Protection. ,30: 1492-1500.

Gwary, D.M., Nahunnaro, H. (1998).Epiphytotics of early blight of tomatoes in Northeastern Nigeria. Crop Prot. 17(8):619-624.

James, W.C. (1971). A manual of assessment keys for plant diseases. Canadian Department of AgricPubl No. 1458, 80 pp

Janisiewicz, W.J. and Peterson, D.L. (2005). Experimental Bin drenching system for testing bio control agents to control postharvest decay of apples. Plant Dis., 89:487-490.

Latha, P., Anand, T., Ragupathi, N., Prakasam, V. and Samiyappan, R. (2009). Antimicrobial activity of plant extracts and induction of systemic resistance in tomato plants by mixtures of PGPR strains and Zimmu leaf extract against Alternariasolani. Biological Control, 50:85-93.

Maya, C. and Thippanna, M. (2015).In vitro antifungal evaluation of various botanical extracts against early blight disease (Alternariasolani) of tomato.I.J.S.N., 6(2):264-267.

Özcan, M. and Boyraz, N. (2000).Antifungal properties of some herb decoctions.European Food Research and Technology, 212: 86-88.

Pane, C. and Zaccardelli, M. (2014). Evaluation of Bacillus strains isolated from solanaceousphylloplane for biocontrol of Alternaria early blight of tomato. Biological Control, 84: 11-18.

Prajapati, H.N., Panchal, R.K. and Patel, S.T. (2014). Efficacy of bioagents and biological interaction of Alternariasolani with phylloplanemycoflora of tomato.Journal of Mycopathological Research, 52: 81-86.

Ramanujam, B., Sriram, S., Rangeshwaran,R. and Basha, H. (2015). Biocontrol efficacy of 
fungal and bacterial antagonists against early blight of tomato caused by Alternariasolani.Indian Journal of Horticulture, 72: 147-148.

Samuels, G.J., Chaverri, P., Farr, D.F. and McCray, E.B. (2009).Trichoderma online, systematic mycology and microbiology laboratory, $\quad$ ARS, USDA.http://nt.arsgrin.gov/taxadescriptions/keys/TrichodermaIndex .cfm.

Sherf, A.F. and MacNab, A.A. (1986).Vegetable diseases and their control. John Wiley and Sons, New York. 634-640 pp.

Spletzer, M. E. and Enyedi, A. J. (1999). Salicylic Acid Induces Resistance to Alternariasolani in Hydroponically Grown Tomato. The American Phytopathological Society, 89(9):722-727.

Townsend, G.R. and Heuberger, J.W. (1943).Method for estimating losses caused by diseases in fungicide experiments. Plant Dis., Reptr., 27:340.

Tran, N. H. (2010). Using Trichodermaspecies for biological control of plant pathogens in Vietnam. J. ISSAAS, 16 (1):17-21.

Wszelaki, A. L. and Miller, S. A. (2005).Determining the efficacy of disease management products inorganically produced tomatoes. Plant Health progress. Vol., pp.17.Online. Plant Health Progress doi: 10.1094/PHP-2005-0713-01-RS.

Yazici, S., Yanar, Y. and Karaman, I. (2011). Evaluation of bacteria for biological control of early blight disease of tomato.African Journal of Biotechnology, 10:9.

Zghair, Q. N., Lal, A. A., Mane, M. M., Sobita, S. (2014).Effect of bioagents and fungicide against early blight disease of tomato (Lycopersiconesculentum L.).International Journal of Plant Protection, 7(2: 330-333.

\section{فاعلية بعض المعاملات الحيوية والغير حيوية فى مقاومة فطر الالترناريا سولانى المسبب لمرض اللفحة المبكرة فى الطماطم تحت ظروف المعمل والصوية

يعتبرمرض اللفحة المبكرة المنسبب عن فطر Alternariasolani واحدا من أمراض المجموع الخضرى الثنائعة على الطماطم. وفى هذا

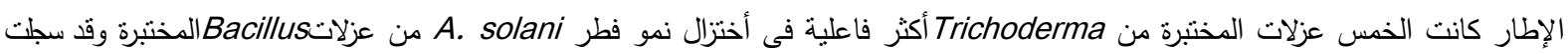

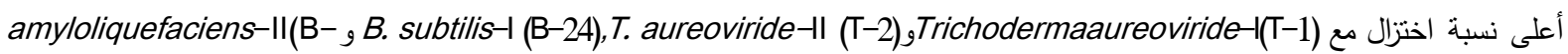

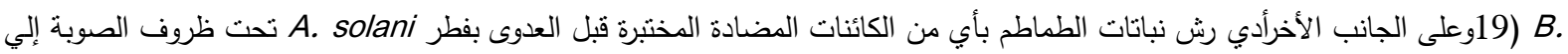

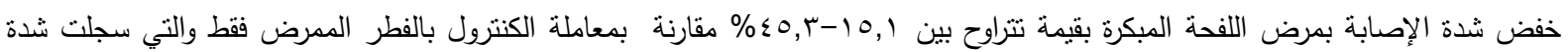

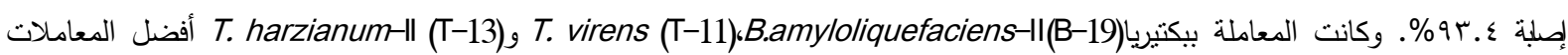
لمقاومة اللفحة المبكرة عند اليوم إ بعد العدوى. أيضا سجلت كل الزيوت المختبرة خفضا في نمو الفطر للعزلة (As-3) solani(As بأفضلية

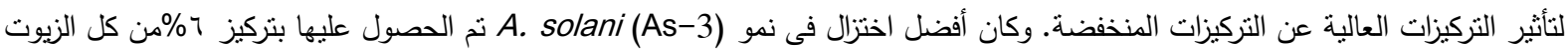
المختبرة. من بين الزيوت النباتية المختبرة كان زيت القرفة أفضل زيت ثم يليه زيت القرنفل ثم زيت البردقوش. ثبينما كان زيت الثيت الثوم أقل الزيوت

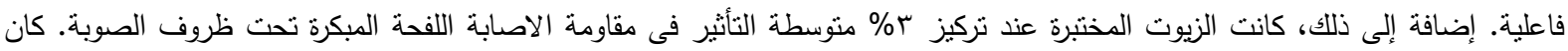
زيت القرنفل والبردقوش أفضل الزيوت النباتية فى خفض الاصابة بمرض اللفحة المبكرة عند اليوم اب بعد العدوى بالممرض على الترتيب. بينما كان زيت الثوم أقلهم تأثيرا.على الجانب الأخر كل المستحثات الكميائية اختزلت نمو (As-3olani(As على أطباق بيئة مستخلص البطاطس.

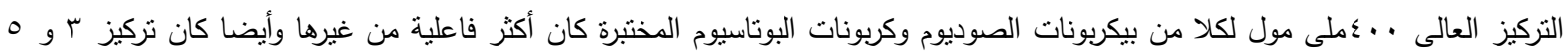
ملى مول أكثر فاعلية فى اختزال A.solani(As-3) مقارنة بنفس النزكيزات لحمض الاسكوربيك، شرث النباتات الطماطم بالمستحثات الكميائية المختبرة (أملاح معدنية وأحماض عضى اكتية) ضد مرض اللفحة المبكرة المنسبب عن فطر (As-3 solani(As كانت منوسطة التأثير فى مقاومة

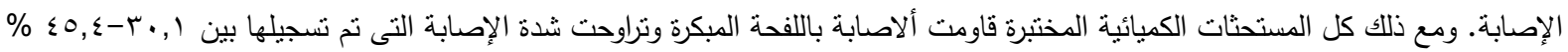
عند اليوم إب بعد العدوى بفطر دمابهر كان رش نباتات الطماطم بحمض السالسيلك أفضل المعاملات فى مقاومة الإصابة بفطر A. solani(As-3)

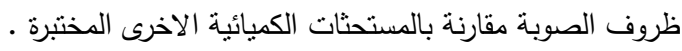
الكلمات الدالة . 